\title{
Masculinization of Tropical Eel Anguilla bicolor McClelland in Different Population Density
}

\author{
Farida Nur Rachmawati* and Yulia Sistina \\ Faculty of Biology, Jenderal Soedirman University \\ Jl. Dr. Soeparno No 63 Purwokerto 53122, Indonesia \\ Email: farida.rachmawati@unsoed.ac.id
}

\begin{abstract}
In general, female eel dominates the results of catching eel in the river. Male fish dare rarely found in nature, therefore masculinization is necessary for obtaining in males. The administration of $17 \alpha$-methyltestosterone to masculinize Anguilla bicolor McClelland. It is a synthetic anabolic-androgenic steroid which has potential to endocrine disrupter that disturbed function of normal reproduction in human or animal. It urgently needed that a masculinization technique needs to study the use of an environmental factor. Population density is one of the environmental factors that influence gender determination (ESD-environmental dependent sex determination). This will result in increased cortisol secretion, which will further stimulate the synthesis of 11-KT steroids that affect male gonad differentiation. This study aims to induce masculinization in tropical eel Anguilla bicolor McClelland in different density. Three treatments and three replicates conducted the research. The treatments were one fish.48 $L^{-1}$, two fish. $48 L^{-1}$ and three fish. $48 L^{-1}$. Eels size was approximately similar, at 16,78 $g \pm 0,62$ in weight, and 25,38 $\mathrm{cm} \pm 0,15$ in length were either culture in brackish water for eight weeks. The results showed that density population treatment significantly increased the Fin Index $(P<0.05)$, but no sign for Eye Index, GSI, HSI, and testosterone level. The highestmale population $(77,8 \%)$ achieves at the highest density treatment, three fish. $48 \mathrm{~L}^{-1}$ population density. It can be concluded, based on reproductive observations, population density does not affect gonad maturity/puberty, but the high population density ( 3 fish. $\left.48 \mathrm{~L}^{-1}\right)$ stimulates Anguilla bicolor McClelland masculinization.
\end{abstract}

Keywords: Anguilla bicolor, masculinization, population density

\section{Introduction}

Indonesian waters are the center of eel distribution (Arrai et al., 2012). Anguilla bicolor McClelland is one type of tropical eel often found in Indonesia and is an export commodity in the fishing industry (Rachmawati et al., 2017). The increasing number of demands for these types of fish certainly has an impact on increasing the exploitation of eel in nature, especially seeds, both glass eels and elvers (Macri et al., 2014; Tanaka, 2015; Dekker, 2016). Based on observations, there was a decline in natural eel resources, especially in eel Anguilla japonica, $A$. rostrata and $A$. anguilla (Nagel et al., 2012, Rupia et al., 2013; Harisson et al., 2014) So, it is also possible that this will be experienced by tropical eel fish $A$. bicolor. Therefore, to maintain the availability of eel biological resources, an artificial hatchery effort must be carried out immediately. However, this effort is not easy considering that until now, to get eel in culture with mature gonads, especially $A$. bicolor has not been successful yet.

The availability of gonad male and mature female fish is the main ingredient in the spawning process. But the difficulty of getting male eel in nature is one obstacle to carrying out artificial spawning stages. Therefore, as an initial step, efforts need to be made to provide male eel through environmental factors. This effort is not easy for the fish with no dimorphism sexual, no morphological differences between males and females, so it is necessary to do masculinization techniques to obtain male individuals. The success of A. bicolor eel's reproductive process requires readiness of the gonad maturity between male and female individuals. This can be done by stimulating gonad maturation through hormone induction and environmental manipulation (Mordenti et al., 2012; Nowosad et al., 2014). However, the decline in the population of eel in the wild resulted in a decrease in the male eel population, even from some samplings that have been done has not found male eel (Rachmawati et al., 2009; 2011; 2017). Therefore, efforts have been made to direct the male sex of $A$. bicolor tropical eel through the treatment of methyltestosterone and salinity. The use of methyltestosterone to produce sex in Teleostei fish has been widely carried out and has proven effective in directing the sex of tropical eel (Rachmawati et al., 2018). 
Sex determination in the animal can be detected in a variety of ways, such as morphometry in goby fish (Sari and Zakaria, 2017); and in parakeet bird (Baehaqi et al., 2018). The sex of eel is not only determined by genetic factors but also by environmental factors, such as population density and salinity (Tesch, 2003). Low-density maintenance will stimulate the development of gonads into females, while at high-density maintenance spur the development of gonads into males (Robak, 2005; Arai and Kadir 2017).

Masculinization or direction of male sex in fish can be done by administering androgen hormones, such as testosterone, 11-keto-testosterone, and synthetic hormone methyltestosterone (Yeh et al., 2003) and environmental manipulation (Chen et al., 2013). Thus, it is necessary to examine the manipulation of environmental factors on the masculinization of the tropical eel $A$. bicolor. Population density is one of the environmental factors that influence gender determination (ESDenvironmental dependent sex determination). This will result in increased cortisol secretion, which will further stimulate the synthesis of 11-KT steroids that affect male gonad differentiation (Fernandino et al., 2013). This study aims to induce masculinization in tropical eel Anguilla bicolor McClelland in different population density.

\section{Materials and Methods}

The eel was obtained from Fisherman, Cilacap. First, fish acclimated for about a week on the fiber aquarium $\left(220 \times 120 \times 40 \mathrm{~cm}^{3}\right)$ filled with 528 liters water. During the acclimation, the eels are fed ad libitum. After the acclimation, fish was transferred to the fiber experiment aquarium $\left(40 \times 50 \times 60 \mathrm{~cm}^{3}\right)$ filled with $1 / 3$ volume of brackish water based on the treatment. Treatments are three different density: 1; 2; or three fish in $48 \mathrm{~L}$ brackish water each in 144L volume of experiment aquarium. Each treatment three-time replicated. During cultured for eight weeks, the eel was fed with commercial feed (PT LABAS Indonesia) once a day at $5 \mathrm{pm}$ as much as 3\% of body weight for eight weeks cultured in brackish water (15 ppt).

At week 8 of treatments, eels were anesthetized with clove oil five ppm for about 30 minutes (Rachmawati and Susilo, 2009). Then, the fish were weighed using a technical scale, and the body length was measured using a ruler, eye diameter, and pectoral fin length were measured using calipers. Fish then were dissected through the abdomen from the anus to the pectoral for gonadal isolation. Gonad was weighed using an analytical scale (Explorer OHAUS) for measuring the GSI (Gonadosomatic Index).

To get eye diameter, the horizontal $(A)$ and vertical diameter (B) of the orbital eye were measured using calipers. Eye Index is $\{(A+B) / 4\} 2 x$ $\Pi$ / Body Length (mm) x 100 (Yokouchi et al., 2009). Measurement of pectoral fin length using calipers by measuring the length of the fins (F.L.) ranging from base to tip. Fin index is $\mathrm{FL}(\mathrm{mm}) /$ Body Length $(\mathrm{mm}) \mathrm{x}$ 100 (Yokouchi et al., 2009). The calculation of GSI value refers to Rupia et al. (2013).

The gonads were then fixed in the NBF solution for the Paraffin Method preparation sample, followed by Hematoxylin-Eosin. The gonadal histology structure analysis refers to Arai and Abdul Kadir (2017) to evaluate sex and gonad maturity status.

\section{Experimental design}

This experimental study applied three different densityastreatments, namely three different density: 1; 2; or three fish in 48L brackish water each in $144 \mathrm{~L}$ volume of experiment aquarium. Each treatment was three-time replicated. Eels size was approximately similar, at 16,78 $\mathrm{g} \pm 0,62$ in weight, and $25,38 \mathrm{~cm} \pm 0,15$ in length were either culture in freshwater or brackish during the experiment for eight weeks. The observed variables were survival rate, sex, Eye Index, and Fin Index and histologic structure of gonad. The research was conducted at Experiment Station and Animal Physiology Laboratory of Biology Faculty Unsoed from February until April 2018. Data obtained from the study: One-way ANOVA analyzed eye index and fin index, and the number of males and the histological structure of gonads data were analyzed descriptively (De Smith, 2018).

\section{Results and Discussion}

Tropical eel $A$. bicolor culture in three densities resulted in the highest percentage of the male population of $77.78 \%$ found in the treatment with the highest population density, namely three fish.48L-1 brackish water (Figure 1.). As reported in Figure 1, the sex of eel was based on descriptive histological results from each of their histological assessment of each gonad of the eel, male if the gonad is testes, female if the histological gonad is the ovary.

Eel sex can be determined by the environment (ESD: Environmental Sex Determination) (Degani, 2016). According to Degani (2016), population density is one of the environmental factors that influence sex determination. Eel fish that are kept at low population densities tend to produce 
female individuals, whereas, at high population densities, it has dominant male individuals. Low population density stimulates $\mathrm{Gn}-\mathrm{RH}$ to secrete $\mathrm{FSH}$, thereby influencing steroidogenesis, aromatase synthesis (CYP19), and 17ß-estradiol from 11ketotestosterone (Kt-1) which causes ovarian development (Degani, 2016). Estradiols secretion in the ovaries influences the activation of polypeptides which are stimulated by the enzyme adenylatecyclase (PACAP), growth hormone, and IGF (Insulinlike growth factor) (Degani, 2016). In contrast, the high density of eel fish causes the pituitary gland to secrete FSH at a low level, so CYP19 is not synthesized. Furthermore, Kt-11 secretion influences gonad differentiation into the testes, which inhibits the somatic axis in decreasing the growth rate (Degani, 2016).
Report on $A$. anguilla in the elver stage maintained at densities of 800,1600 , and $3200 \mathrm{~g}$ m3 produced the highest male population of $96 \%$ at the highest density of $3200 \mathrm{~g} \mathrm{~m}^{3}$ (Roncarati et al., 1997). A. Anguilla glass eel stage, which is maintained at a high population density of $10 \mathrm{~kg} \mathrm{~m} 3$, produces the highest male population equal to to72.5\% (Huertas and Cerda, 2006).

Reproductive characters of Tropical eel $A$. bicolor McClelland treated in different densities, resulted in eye index value (E.I.), Gonad Maturity Index (GSI), Hepatosomatic Index (H.S.) and testosterone levels were not significantly different $(P>0.05)$ among treatments except fins index value which were significantly different $(P<0.05)$. The results of this study indicate that the dense treatment

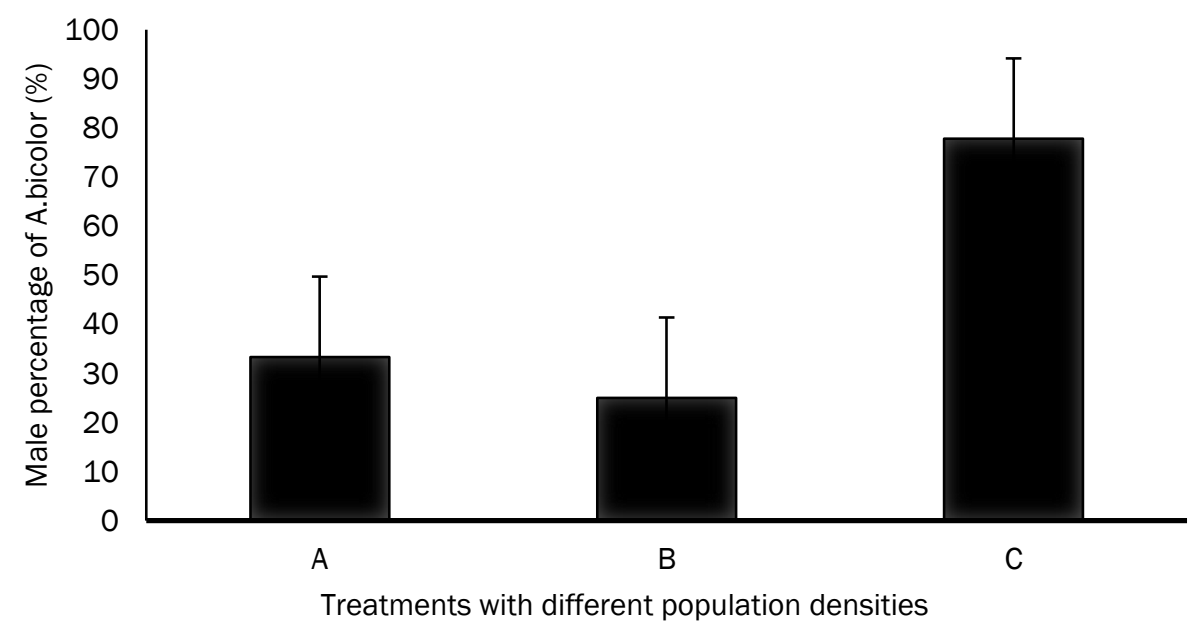

Figure 1. Percentage of the male population of $A$. bicolor, which is kept in different density of one fish. $48 \mathrm{~L}^{-1}(\mathrm{~A})$; two fish.48 $\mathrm{L}^{-1}($ (B) and three fish. $48 \mathrm{~L}^{-1}(\mathrm{C})$.

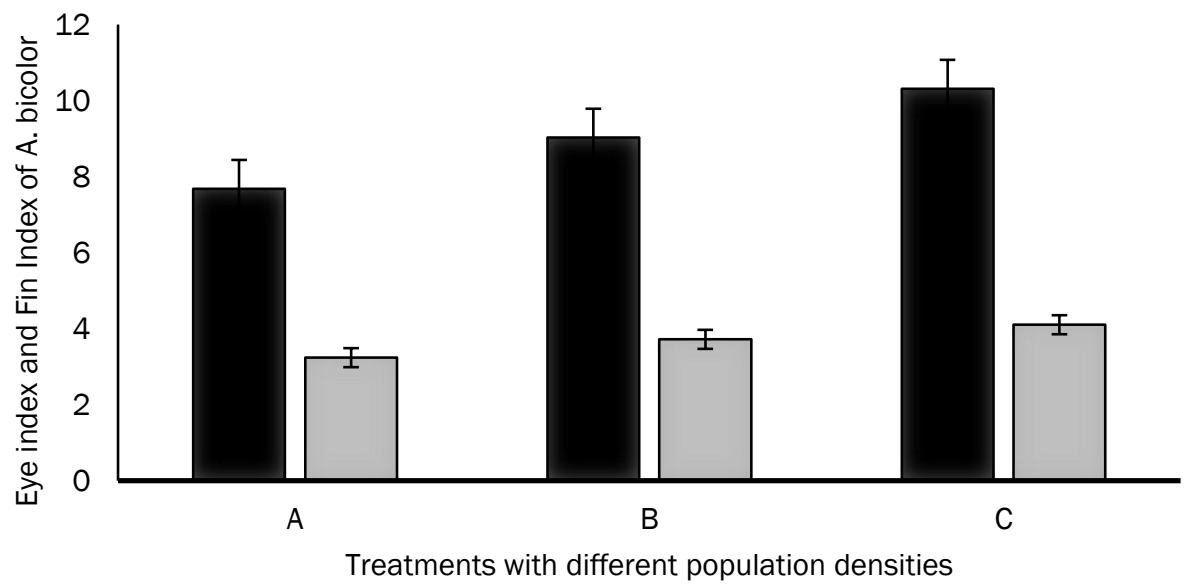

Figure 2. Average eye index (EI) and Fins Index (FI) of A. bicolor in different density of one fish.48 $\mathrm{L}^{-1}(\mathrm{~A})$; two fish.48 $\mathrm{L}^{-1}$ ( (B) and three fish.48 $\mathrm{L}^{-1}(\mathrm{(C)}$.. Note: $\square=\mathrm{El} ; \square=\mathrm{FI}$ 


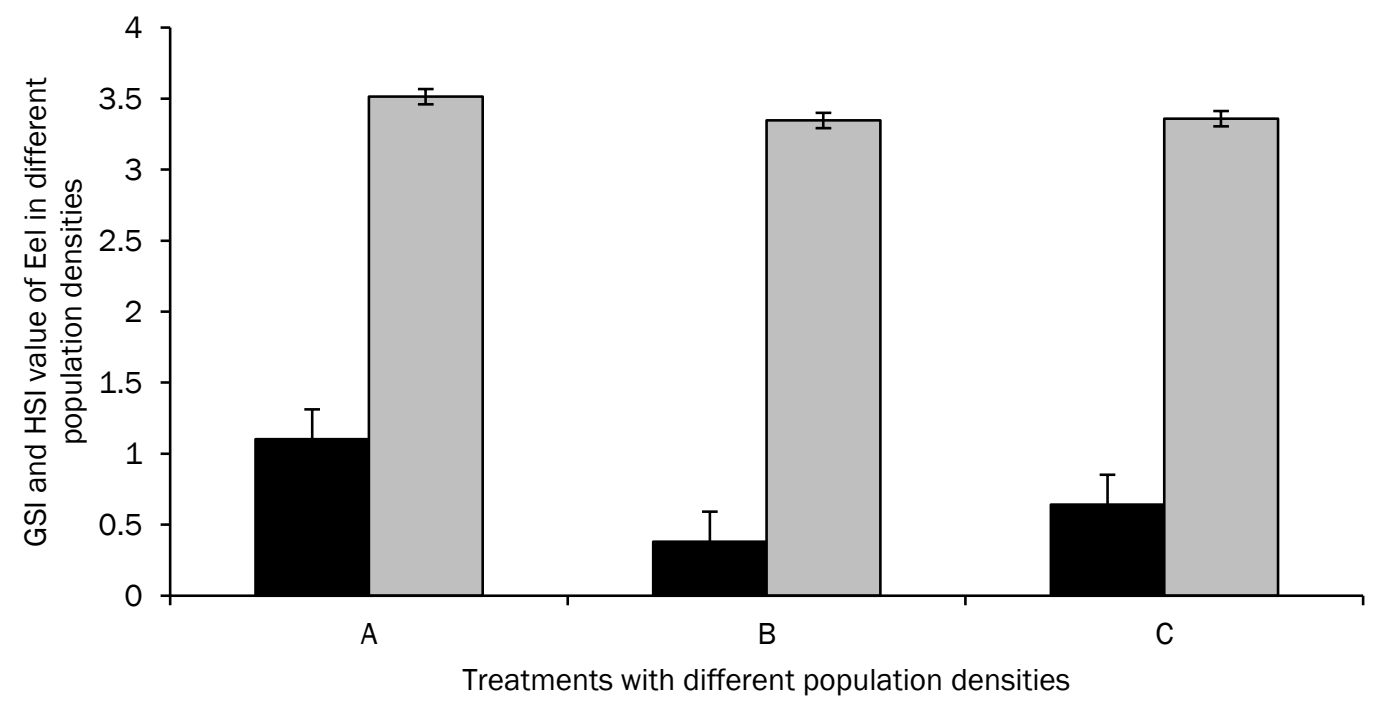

Figure 3. Average Gonado somatic index (GSI) and hepatosomatic index (HSI) of A. bicolor in different density of one fish.48 $\mathrm{L}^{-1}$ (A); two fish.48 $\mathrm{L}^{-1}($ (B) and three fish.48 L-1( (C).. Note: $\mathbf{\square}=\mathrm{GSI}$; $\square=\mathrm{HIS}$

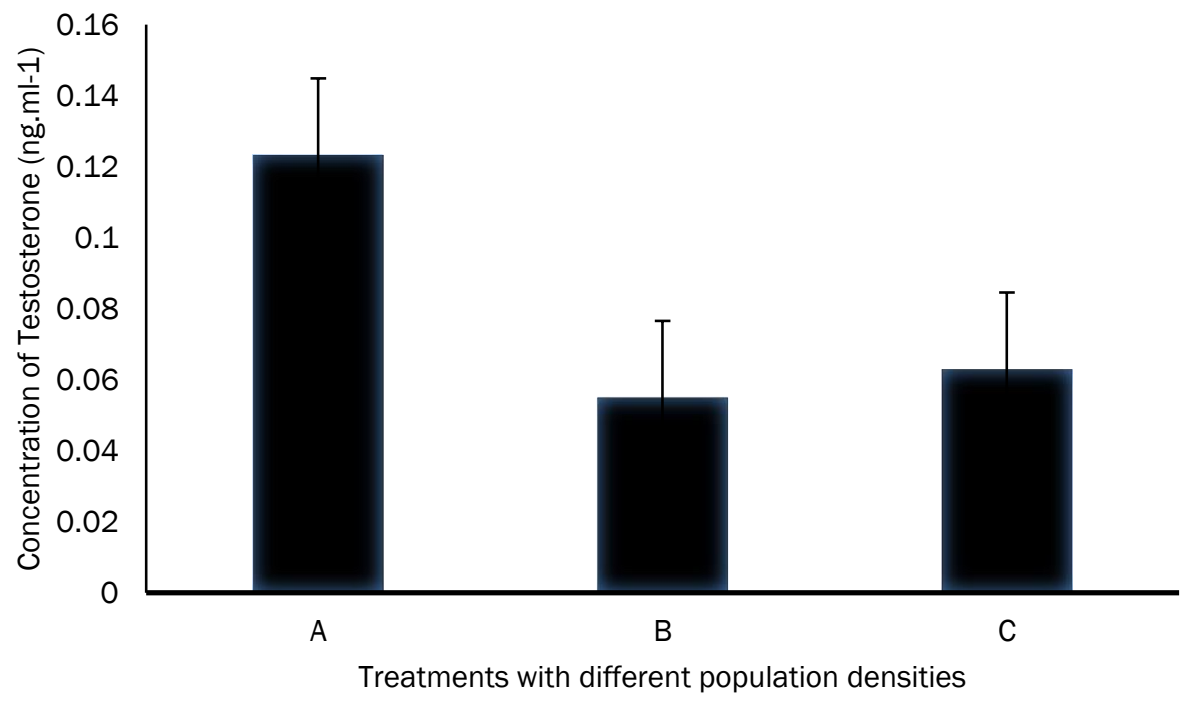

Figure 4. Average Testosterone (ng.ml-1) levels of $A$. bicolor in different density of one fish. $48 \mathrm{~L}^{-1}(\mathrm{~A})$; two fish.48 $\mathrm{L}^{-1}((\mathrm{~B})$ and three fish.48 $\mathrm{L}^{-1}(\mathrm{C})$.

of social spreading/interaction does not affect the improvement of gonadal maturity of eel or spur changes in males.

Results proved that the average fin index (F.I.) value and eye index (E.I.) tend to increase as density increases. The higher the density population, their eye index value and the fin index had increased (Figure 2.).

A result of the parameter of testosterone level averages from treated eels was not significantly different $(P>0.05)$, as shown in Figure 4 . This most likely due to at the time measured eels had not on the reproductive stage yet or the juvenile stage. Testosterone levels will increase along with gonad maturity. In this experiment, the testosterone level still low under $0,5 \mathrm{ng} / \mathrm{ml}$. In general, testosterone levels will increase along with the process of migration from freshwater to the sea to complete the process of gametogenesis but also for spawning preparation. This is in line with Hagihara et al. (2019) research results, which shows that there are differences in testosterone levels of migratory and non-migratory eels. The testosterone levels of migratory eels will increase. Testosterone/androgen modulates initial developmental in the previtellogenic ovary (Lee and Lou, 2019). Changes in testosterone 
levels are associated with increased gonad maturity. In this study, eel fish is still in the state of pre-puberty.

\section{Conclusion}

It can be concluded, based on reproductive observations, population density does not affect gonad maturity/puberty, but the high population density (3 fish.48 $\mathrm{L}^{-1}$ ) stimulates Anguilla bicolor McClelland masculinization.

\section{Acknowledgment}

The authors would like to thank LPPM UNSOED, who has facilitated the acquisition of a research fund that has facilitated this research in the Competitive Grant Research of Competency Research Scheme of Fiscal Year 2018/2019. Also, thanks to Untung Yulianto, technician staff of the Experiment Station Laboratory of Faculty of Biology UNSOED, who has assisted in the maintenance of eels during this research.

\section{References}

Arai, T. \& Abdul Kadir, S.R. 2017. Opportunistic spawning of tropical anguillid eels Anguilla bicolor bicolor and $A$. bengalensis bengalensis. Sci. Reports, 7(1):1-17. doi: 10.1038/srep416 49

Baehaqi, I., Saraswati, T.R. \& Yuniwarti, E.Y.W. 2018. Sex Determination in Male and Female Melopsittacus undulates using a Morphometric Method. J. Biol. Biol. Educ., 10(3): 533-538. doi: 10.15294/biosaintifika.v10i3.14067

Bark, A., Williams, B. \& Knights, B. 2007. Current status and temporal trends in stocks of European eel in England and Wales. ICES J. Mar. Sci., 64(7): 1368-1378. doi: 10.1093/icesjms/ fsm117

Chen, J., Hu, W. \& Zhu, Z. 2013. Progress in studies of fish reproductive development regulation. Chinese Science Bulletin, 58(1):7-16. doi: 10.1007/s11434-012-5577-1.

Degani, G. 2016. A model of hormonal and environmental involvement in growth and sex differentiation in European eel (Anguilla anguilla). Adv. Biol. Chem., 6:41-145. doi: 10.4236/abc.2016.64012
Dekker, W. 2016. Management of the eel is slipping through our hands! Distribute control and orchestrate national protection. J. Mar. Sci., 73(10):2442-2452. doi: 10.1093/icesjms/fsw 094.

De Smith, M.J. 2018. A Comprehensive Handbook of Statistical Concept, Techniques and Software Tools. The Winchelsea Press, Drumlin Security Ltd, Edinburgh. 660 pp.

Fernandino, J.I., Ricardo, S.H., Omar, D.M. \& Carlos, A.S. 2013. Environmental stress-induce testis diffenrentiation: Androgen as by a product of cortisol inactivation. Gen. Comp. Endocrinol., 192:36-44. doi: 10.1016/j.ygcen.2013.05.024

Geffroy, B. \& Bardonnet, A. 2015. Sex differentiation and sex determination in eels: Consequences for management. Fish and Fisheries, John Willey \& Sons Ltd. Pp. 1-24. doi: 10.1111 /faf.12113.

Hagihara, S., Aoyama, J., Sudo, R., Limbong, D., Ijiri, Sh., Adachi, Sh. \& Tsukamoto, K. 2019. Reproductive Physiological Characteristics Of Tropical Celebes Eels Anguilla Celebesensis In Relation To Downstream Migration And Ovarian J. Fish Biol., 96(3):558-569. doi: 10.1111/jfb. 14231.

Harisson, A.J., Walker, A.M., Pinder, A.C., Briand, C., \& Aprahamian, M.W. 2014. A review of glass eel migratory behaviour, sampling techniques and abundance estimates in estuaries: implications for assessing recruitment, local production and exploitation. Rev. Fish Biol. Fisheries. 24(4): 967-983. doi: 10.1007/s11160-014-9356-8

Huertas, M. \& Cerda, J. 2006. Stocking density at early developmental stages affects growth and sex ratio in the European Eel (Anguilla anguilla). Biol. Bull. 211:286-296. doi: 10.2307/41 34550

Lee, S.C. \& Lou, S.W. 2019. Androgenic modulation in the primary ovarian growth of the Japanese eel, Anguilla japonica. Zoolog. Stud., 58:2-17. doi: 10.6620/ZS.2019.58-02.

Macri, F., Rapisarda, G., De Stefano, C., De Majo, M., Bottari, T. \& Aiudi, G. 2014. Coelioscopic investigation in European eels (Anguilla anguilla). J. Exotic Pet Med., 23:147 -151. doi: 10.1053/j.jepm.2014.02.014

Mordenti, O., Di Biase, A., Sirri, R., Modugno, S. \& Tasselli, A. 2012. Induction of sexual maturation in wild female European eels 
(Anguilla anguilla) in darkness and light. Israeli J. Aquacul., 64:726-735

Nagel, F., Wagner, C., Hanel, R. \& Kamman, U. 2012. The Silvering process of European (Anguilla anguilla) influensces $\mathrm{PAH}$ metabolite concentrations in bile fluid: Consequences for monitoring. Chemospher., 87(1): 91-96. doi: 10.1016/j.chemosphere.2011.11.071

Tanaka, H. 2015. Progression in artificial seedling production of Japanese eel Anguilla japonica. Fish Sci., 81:11-19. doi: 10.1007/s12562014-0821-z.

Rachmawati, F.N., \& Susilo, U. 2009. Perkembangan Gonad Ikan Sidat, Anguilla bicolor Ditinjau dari Titer Hormon Gonadotrophin. Sains Akuatik, 10(2):148 - 154.

Rachmawati, F.N. \& Susilo, U. 2011. Profil Hormon dan Kinerja Reproduksi Ikan sidat, Anguilla bicolor McClelland. Biota, 16 (2):221 - 226.

Rachmawati, F.N., \& Susilo, U. 2012. Kajian Histologi Ikan Sidat, Anguilla bicolor McClelland, yang tertangkap di Segara Anakan Cilacap. Berkala Penelitian Hayati, 18(1):47-49.

Rachmawati, F.N., Susilo, U., \& Muslih. 2017. Karakteristik reproduksi ikan sidat Anguilla bicolor McClelland, 1844 yang diinduksi GnRHanalog. J. Iktiologi Indo., 17(2):155-63.

Rachmawati, F.N., Affandi, R., \& Sistina, Y. 2018. Effectively of 17- $\alpha$ Methyltestosterone on tropical eel Anguilla bicolor McClelland masculinization in different salinity culture . Omni-Akuatika, 14(2):73 - 78.

Robak, S. 2005. Sex structure, recruitment rate, and size of maturing specimens of European eel (Anguilla anguilla L.) in a population from lakes in North eastern Poland. Archives of Polish Fisheries 13(2):181-92

Roncarati, A., Melotti, P., Mordenti, O. \& Gennari, L. 1997. Influence of stocking density of European eel (Anguilla anguilla, L.) elvers on sex differentiation and zootechnical performances. J. App. Ichtyol., 13:131-136.

Tesch, F.W. 2003. The Eel. Blackwell Science, Oxford, U.K., 408 pp.

Yokouchi, K., Sudo, R., Kaifu, K., Aoyama, J. \& Tsukamoto, K. $2009 . \quad$ Biological Characteristics of Silver-Phase Japanese Eels, Anguilla japonica, Collected from Hamman Lake, Japan. Coast. Mar. Sci., 33(1):1-10. 